\title{
USE OF SURFACTANT WITH DIFFERENT VOLUMES OF FUNGICIDE APPLICATION IN SOYBEAN CULTURE
}

\author{
Rafael Roehrig $^{1 *}$, Walter Boller ${ }^{2}$, Carlos A. Forcelini ${ }^{2}$, Amanda Chechi ${ }^{2}$
}

1* Corresponding author. Programa de Pós-Graduação em Agronomia - Universidade de Passo Fundo/ Passo Fundo - RS.

E-mail: rafael.roehrig@yahoo.com.br

\section{KEYWORDS}

leaf surface cover, Phakopsora pachyrhizi, application rate.

\begin{abstract}
Application volume, adjuvants that act on the drop surface tension and droplet spectrum are the main factors affecting leaf surface coverage and the spray penetration droplets inside the canopy of the soybean crop, which may have an impact on fungicide efficiency, since those used in the handling of Asian-rust, including those that are absorbed by the plant, present a small displacement from the point of deposition. Thus, it was sought to determine the impacts on the use of the organosilicone surfactant compared to the changes in the spray volumes. For that, five spray volumes and the combination of two adjuvants were compared in randomized blocks with a factorial arrangement $5 \times 2$. Reductions in volume negatively impacted the number of drops $\mathrm{cm}^{-2}$ affecting the leaf surface cover which did not exceed $13 \%$ in the lower third, in the absence of the surfactant. Also, the reduction in the volume provided decreases in the control of Asian- rust, and the use of surfactant minimized the negative impacts of the disease, reflecting on the index of the leaf area which varied up to 6.5 times on changes in the spray volume, and up to 2.8 times against the use of the surfactant in relation to the mineral oil isolated. Grain yield was negatively affected as reductions in the spray volumes, occurred with less impact when the surfactant was used. Thus, coverage of the leaf surface and the number of drops $\mathrm{cm}^{-2}$ along the plant profile respond to the addition of the surfactant and to the increase of the spray volume, having relation with the control of soybean Asian-rust, and affecting the leaf area index and productivity.
\end{abstract}

\section{INTRODUCTION}

Asian soybean rust (ASR) caused by the fungus Phakopsora pachyrhizi is one of the most severe diseases affecting soybean cultivation, with damages varying from 10 to $90 \%$, and damage being observed in order of $50 \%$ in Paraguay, 80\% in Australia and 55\% in Brazil (Reis et al., 2012). Still, the losses accounted for 21 billion dollars in Brazil between 2002 and 2013 (Godoy et al., 2016).

A number of management practices can and should be adopted to reduce ASR impacts. The restriction of soybean cultivation at certain seasons of the year, the elimination of volunteer plants and the elimination of intermediate hosts, allied to sowing at the beginning of the recommended season and the use of early-cycle cultivars (Godoy et al., 2016; Almeida et al., 2017), combined with changes in cultural practices such as plant arrangement and irrigation management (Madalosso et al., 2010; Holtz et al., 2014) besides the varietal resistance (Melo et al., 2015) and application of fungicides (Godoy et al., 2016) are integrated measures for the management of ASR, becoming relevant for the sustainability of the culture (Godoy et al., 2016, Langenbach et al., 2016, Kimati et al. , 2011).

The use of fungicides is one of the main strategies for ASR management, where control effectiveness depends on the fungicide efficiency, timing and applications frequency as well as the adjustment on application technology to the target and crop (Cunha \& Silva, 2010). However, the results in terms of control are not always satisfactory since it starts in the lower third of the plant leaves. Thus, fungicide sprays must overcome the imposed barrier by the leaf mass to reach the target, as well as promote adequate coverage within the crop canopy (Debortoli et al., 2012; Tormen et al., 2012). In addition to aspects inherent to the deposition of the fungicide on the target, these have generally shown reductions in efficacy, given the selection pressure caused on the fungus resulting in control deficiencies (Schmitz et al., 2013; Reis et al., 2015; Godoy et al., 2016).

The coverage provided by fungicide application on the canopy, in general is poorly uniform especially in the lower third of the plant resulting in inefficient control

\footnotetext{
${ }^{2}$ Universidade de Passo Fundo / Passo Fundo - RS, Brasil.

Received in: 2-5-2018

Accepted in: 6-6-2018
} 
(Prado et al., 2010; Cunha et al., 2011), since the deposition of drops in the median and lower third does not exceed $20 \%$, giving rise to gradients up to three times in comparison between the upper and lower third of the plant (Villalba et al., 2009; Cunha et al., 2011).

Although the main fungicides used in the ASR management are classified as penetrating, that is, absorbed by the plant, most of them present loco-systemic action being transported at small distances from the point of deposition, so that for them to express their efficiency it is necessary the adequate distribution along the crop canopy, as well as on the foliar surface (Cunha et al., 2014; Reis et al., 2010). Due to the need for adequate foliar coverage, ASR control can be affected by application volumes, droplet size and the use of adjuvants that act on the sprinkling of droplets (Cunha et al., 2014).

The use of low-volume fungicide sprays, which appear as an alternative to increase the operational capacity of sprayers may adversely, affect the effectiveness of ASR control in certain situations (Cunha et al., 2008; Cunha et al., 2014), since the increase in the spray volume used has an effect on leaf cover (Cunha et al., 2006). However, spraying with larger volumes reduces the sprayed area per unit time, therefore becoming more and more common to reduce the spray volume in fungicide applications, even at the risk of reducing effectiveness.

The addition of surfactant adjuvants to the tank mixture can optimize the efficiency of the applications, since these can improve mainly the adherence and the spreading of the drops containing the fungicide on the target (Cunha et al., 2014), once reduces the surface tension of the solution and consequently the contact angle of the drops with the surfaces, increasing the coverage (Spanoghe et al., 2007; Prado et al., 2015). The oil-based adjuvants, associated with surfactants, have positive effects as wetting, spreading, penetrating, anti-evaporating, besides improving translocation, retention and adhesive effect (Chechetto et al., 2013; Prado et al., 2015). Thus, the combination of both surfactant and oil-based adjuvants appears as an alternative to optimize the fungicide effect.

The objective of this study was to determine the impacts of the use of organosilicone surfactant compared to the changes in the application volumes regarding to ASR control levels. In addition, it was sought to determine if the spray volume used and the use of surfactant interfere with the cover leaf surface and its relationship with ASR control with leaf area index (LAI) and grain yield.

\section{MATERIAL AND METHODS}

The study was conducted during the 2015/2016 season, at the experimental field of Passo Fundo University, Passo Fundo, RS, at an altitude of $687 \mathrm{~m}$, latitude $28^{\circ} 15^{\prime} \mathrm{S}$ and longitude $52^{\circ} 24^{\prime} \mathrm{W}$. The Nidera 5909 RR soybean cultivar was used with an indeterminate growth habit, semi erect with a branching potential, susceptible to ASR.

Five spray volumes $\left(40,70,100,130\right.$ and $160 \mathrm{~L} \mathrm{ha}^{-}$ ${ }^{1}$ ) were combined with two adjuvants (Nimbus ${ }^{\circledR}$ (mineral oil) and Nimbus ${ }^{\circledR}$ plus Break Thru ${ }^{\circledR}$ (surfactant)), and the treatments were conducted in randomized blocks with three replicates arranged in a $5 \times 2$ factorial scheme. The experimental units measured $20 \mathrm{~m}$ in length and $5.85 \mathrm{~m}$ in width (13 rows spaced in $0.45 \mathrm{~m}$ ), totaling $117 \mathrm{~m}^{2}$.

The soybean sowing was carried out on December 7 , 2015 , in succession to wheat, in an area with soil type Red Latosol, with final population of 295,000 plants ha-1. Fertilization, management of weeds and pests was carried out in accordance with the technical recommendations for the crop. Four fungicide applications were carried out using five different spray volumes combined with two adjuvants, been the mineral oil-based adjuvant used in the concentration of $256.8 \mathrm{~g} \mathrm{ha}^{-1}$ and the surfactant at $0.1 \%$ volume.

The first fungicides application occurred in the V7 stage (Fehr et al., 1971), where the fungicides propiconazole + diphenoconazole $(37.5+37.5$ grams of active ingredient $\mathrm{ha}^{-1}$ ) were used in combination with azoxystrobin + cyproconazole $(60+24$ grams of active ingredient $\mathrm{ha}^{-1}$ ). In the second application (R1 stage - Fehr et al., 1971) and in the third application, 18 days after R1, it was used the fungicide mixture composed by azoxystrobin + benzovindiflupir $(60+30$ grams of active ingredient ha $\left.{ }^{1}\right)$. In the fourth application, 33 days after R1, the used fungicide was composed by mixture of azoxystrobin + cyproconazole $\left(60+24\right.$ grams of active ingredient ha- $\left.\mathrm{ha}^{-1}\right)$.

The variations in the spray volumes $\mathrm{ha}^{-1}$ were due to the use of spray nozzles with different flow rates, calibrated for medium-sized droplet spraying, according to information cataloged by the manufacturer (Table 1). The applications were sprayed with a sprayer attached to the tractor using a sprayer bar with length of $6.0 \mathrm{~m}$, with the nozzles spaced $0.50 \mathrm{~m}$ and kept $0.50 \mathrm{~m}$ above the crop canopy. In order to operate in favorable environmental conditions all applications were performed in the morning (Table 2).

TABLE 1. Spray volume $\left(\mathrm{L} \mathrm{ha}^{-1}\right)$, spray nozzles, working pressure $(\mathrm{kPa})$, application speed $\left(\mathrm{km} \mathrm{h}^{-1}\right)$ and adjuvant used in each treatment, Passo Fundo - RS, 2018.

\begin{tabular}{|c|c|c|c|c|c|}
\hline Treatment & $\begin{array}{l}\text { Volume } \\
\left(\mathrm{L} \mathrm{ha}^{-1}\right)\end{array}$ & Nozzle & $\begin{array}{c}\text { Pressure } \\
(\mathrm{kPa})\end{array}$ & $\begin{array}{l}\text { Velocity } \\
\left(\mathrm{km} \mathrm{h}^{-1}\right)\end{array}$ & Adjuvant \\
\hline $\begin{array}{l}1 \\
2\end{array}$ & 40 & TT 11001 & 150 & 8.0 & $\begin{array}{c}\text { Mineral oil } \\
\text { Mineral Oil and Surfactant }\end{array}$ \\
\hline $\begin{array}{l}3 \\
4 \\
\end{array}$ & 70 & TT 110015 & 200 & 8.0 & $\begin{array}{c}\text { Mineral oil } \\
\text { Mineral Oil and Surfactant }\end{array}$ \\
\hline $\begin{array}{l}5 \\
6 \\
\end{array}$ & 100 & TT 110015 & 425 & 8.0 & $\begin{array}{c}\text { Mineral oil } \\
\text { Mineral Oil and Surfactant }\end{array}$ \\
\hline $\begin{array}{l}7 \\
8 \\
\end{array}$ & 130 & TT 11002 & 400 & 8.0 & $\begin{array}{c}\text { Mineral oil } \\
\text { Mineral Oil and Surfactant }\end{array}$ \\
\hline $\begin{array}{c}9 \\
10\end{array}$ & 160 & TT 110025 & 350 & 8.0 & $\begin{array}{c}\text { Mineral oil } \\
\text { Mineral Oil and Surfactant }\end{array}$ \\
\hline
\end{tabular}


The number of drops $\mathrm{cm}^{-2}$, the foliar surface coverage, the ASR severity, the LAI, the grain yield and the mass of one thousand grains (MTG) were evaluated. The MTG and the grain yield were evaluated in the six central rows, the others, in the adjacent rows.

TABLE 2. Averages of the environmental conditions observed during the applications. Passo Fundo - RS, 2018.

\begin{tabular}{ccccc}
\hline Environmental condition & Application 1 & Application 2 & Application 3 & Application 4 \\
\hline Wind speed $\left(\mathrm{km} \mathrm{h}^{-1}\right)$ & 7.1 & 5.9 & 6.9 & 6.4 \\
Relative humidity $(\%)$ & 59 & 61 & 68 & 57 \\
Air temperature $\left({ }^{\circ} \mathrm{C}\right)$ & 27.1 & 26.5 & 25.9 & 26.8 \\
\hline
\end{tabular}

The number of drops $\mathrm{cm}^{-2}$ and the foliar surface cover were evaluated by hydro sensitive cards in the applications performed in R1 (Fehr et al., 1971) and R1 + 18 days where six cards were distributed in each plot in the lower, middle and upper third of the plant. After spraying, the cards were collected, scanned at 1200 dpi resolution and then read in CIR $1.5^{\circledR}$ software. From the six evaluated cards in each third and in each application, the arithmetic mean was done to determine the number of drops $\mathrm{cm}^{-2}$ and the leaf surface cover. In parallel to the evaluation of the number of drops $\mathrm{cm}^{-2}$ and cover of the leaf surface we evaluated the LAI and height of the plants, randomly collected in the experimental area including all treatments, aiming at characterizing plant height at the time of spraying.

The ASR severity was evaluated based on the affected leaf area, using as a reference the diagrammatic scale by Godoy et al. (2006). The evaluations started at the V7 stage and extended to R6 (Fehr et al., 1971), with intervals of 12 to 15 days where in each evaluation four plants were collected and evaluated all the developed leaves. The severity was quantified in the lower, middle and upper third of the plant. The ASR severity was integrated in the area under the disease progress curve (AUDPC), by means of the equation: AUDPC $=\Sigma\left[\left(\left(\mathrm{y}_{1}+\mathrm{y}_{2}\right) / 2\right) *\left(\mathrm{t}_{2}-\mathrm{t}_{1}\right)\right]$, where $y_{1}$ and $y_{2}$ are two consecutive evaluations performed at times $t_{1}$ and $t_{2}$. Based on the AUDPC of the treatment without the application of fungicide, the control of the disease was calculated, comparing the maximum AUDPC of the treatment without fungicides application in relation to those where the application occurred with the different spray volumes and with the different adjuvant combinations.

At the R6 stage (Fehr et al., 1971), six plants were collected in each experimental unit to determine the remaining leaf area of each plant through the leaf area integrator (LI-3100 Area Meter). From these plants, the arithmetic mean was determined and based on the established plant population was determined the LAI.
The harvest was carried out in $54 \mathrm{~m}^{2}$ of each plot, considering the six central lines of each experimental unit through a harvester parcel (Wintersteiger, A-4910), after which the grains were processed. The moisture content and the weight, corrected to $13 \%$ moisture, were determined for grain yield $\left(\mathrm{kg} \mathrm{ha}^{-1}\right)$ and one thousand grain mass $(\mathrm{g})$. In one of the adjacent lines, six plants were collected where the vegetables were manually threshed and the grain mass of each third of the plant was evaluated and then compared in relation to the total grain mass of the plant. Thus, the percentage participation of each third (lower, middle and higher) was calculated in the yield of the plant. Knowing the participation of each third of the plant in the yield and with the possession of the plots grain yield, it was estimated the grains yield in each third of the plant proportionally.

We used the $F$ test for analysis of variance and the Tukey test for comparison of means with the aid of the Assistat ${ }^{\circledR}$ software.

\section{RESULTS AND DISCUSSION}

The analysis of variance for the number of drops $\mathrm{cm}^{-2}$ was only significant for the spray volumes. At the application of R1 the plants had an average height of 1.02 $\mathrm{m}$ and an average LAI of 4.98. In the application at R1 +18 days, the average plant height was $1.18 \mathrm{~m}$ and the average LAI was 5.62.

The increase in the spray volume $\mathrm{ha}^{-1}$ provided an increase in the number of drops $\mathrm{cm}^{-2}$ throughout the plant profile, both in the application performed in $\mathrm{R} 1$ stage, Table 3 , and in that performed in R $1+18$ days, Table 4 , since in the passage from 40 to $160 \mathrm{~L} \mathrm{ha}^{-1}$ there was an increase in approximately 2.1 times the number of drops $\mathrm{cm}^{-2}$. The increase in the spray volume represented up to $33.9 \%$ more deposited drops in the plant when it went from 70 to $100 \mathrm{~L}$ $\mathrm{ha}^{-1}$ and was in the order of $20 \%$ when it was changed from 40 to $70 \mathrm{~L} \mathrm{ha}^{-1}$ and from 100 to $130 \mathrm{~L} \mathrm{ha}^{-1}$ in both evaluation moments. Even in the highest volumes there was an increase in the number of drops $\mathrm{cm}^{-2}$, reaching $8.2 \%$ when the volume was increased from 130 to $160 \mathrm{~L}_{\text {of }} \mathrm{ha}^{-1}$ (Table 3 and Table 4).

TABLE 3. Number of drops $\mathrm{cm}^{-2}$ in R1 stage in the lower, middle and upper third of the plant, as a function of spray volume $\left(\mathrm{L} \mathrm{ha}^{-1}\right)$ in the fungicide applications, Passo Fundo - RS, 2018.

\begin{tabular}{|c|c|c|c|c|}
\hline \multirow{2}{*}{ Volume $\left(\mathrm{L} \mathrm{ha}^{-1}\right)$} & \multicolumn{4}{|c|}{ Number of drops $\mathrm{cm}^{-2}$} \\
\hline & Lower third & Middle third & Upper third & Average \\
\hline 40 & $6.6 \mathrm{e}$ & $33.0 \mathrm{e}$ & $113.8 \mathrm{~d}$ & $51.1 \mathrm{e}$ \\
\hline 70 & $13.0 \mathrm{~d}$ & $42.6 \mathrm{~d}$ & $133.5 \mathrm{c}$ & $63.0 \mathrm{~d}$ \\
\hline 100 & $21.6 \mathrm{c}$ & $52.8 \mathrm{c}$ & $172.2 \mathrm{~b}$ & $82.2 \mathrm{c}$ \\
\hline 130 & $29.8 \mathrm{~b}$ & $63.3 \mathrm{~b}$ & $212.3 \mathrm{a}$ & $101.8 \mathrm{~b}$ \\
\hline 160 & $37.3 \mathrm{a}$ & $74.1 \mathrm{a}$ & 220.6 a & $110.6 \mathrm{a}$ \\
\hline Average & 21.7 & 53.2 & 170.5 & \\
\hline C.V. $(\%)$ & 15.8 & 13.5 & 14.2 & 12.7 \\
\hline
\end{tabular}

Means followed by the same letter do not differ by Tukey test, $5 \%$ probability. 
TABLE 4. Number of drops $\mathrm{cm}^{-2}$ in the R1 stage +18 days in the lower, middle and upper third of the plant, as a function of spray volume $\left(\mathrm{L} \mathrm{ha}^{-1}\right)$ in fungicide applications, Passo Fundo - RS, 2018.

\begin{tabular}{|c|c|c|c|c|}
\hline \multirow{2}{*}{ Volume $\left(\mathrm{L} \mathrm{ha}^{-1}\right)$} & \multicolumn{4}{|c|}{ Number of drops $\mathrm{cm}^{-2}$} \\
\hline & Lower third & Middle third & Upper third & Average \\
\hline 40 & $5.4 \mathrm{e}$ & $32.1 \mathrm{e}$ & $122.7 \mathrm{~d}$ & $53.4 \mathrm{e}$ \\
\hline 70 & $10.8 \mathrm{~d}$ & $40.4 \mathrm{~d}$ & $136.3 \mathrm{c}$ & $62.6 \mathrm{~d}$ \\
\hline 100 & $20.1 \mathrm{c}$ & $54.5 \mathrm{c}$ & $183.5 \mathrm{~b}$ & $86.1 \mathrm{c}$ \\
\hline 130 & $27.5 \mathrm{~b}$ & $62.1 \mathrm{~b}$ & $224.1 \mathrm{a}$ & $104.6 \mathrm{~b}$ \\
\hline 160 & $35.2 \mathrm{a}$ & $72.6 \mathrm{a}$ & $230.6 \mathrm{a}$ & $112.7 \mathrm{a}$ \\
\hline Average & 19.8 & 52.3 & 179.4 & \\
\hline C.V. $(\%)$ & 10.2 & 14.7 & 12.3 & 11.8 \\
\hline
\end{tabular}

Means followed by the same letter do not differ by Tukey test, $5 \%$ probability.

The deposition of drops $\mathrm{cm}^{-2}$, considering the application performed in R1 and R1 + 18 days reduced along the canopy of the plant where on average, the lower third presented reduction 2.5 times in the number of drops $\mathrm{cm}^{-2}$ in relation to the middle third of the plant which presented 3.3 times less drops than the upper third, and the lower third compared to the upper one presented reduction of 8.5 times in the number of drops $\mathrm{cm}^{-2}$ (Table 3 and Table $4)$.

In the lower third of the plant, the increase in the spray volume increased the deposition of drops in the application of R1 (Table 3) and on R1 + 18 days (Table 4) which was 6.1 times higher when the spray volume changed from 40 to $160 \mathrm{~L} \mathrm{ha}^{-1}$, and variations of up to $98.1 \%$ were observed, especially when changed from 40 to $70 \mathrm{~L} \mathrm{ha}^{-1}$ and $75.2 \%$ when used $100 \mathrm{~L} \mathrm{ha}^{-1}$ in relation to $70 \mathrm{~L} \mathrm{ha}^{-1}$. The highest volume, $160 \mathrm{~L} \mathrm{ha}^{-1}$ presented the highest number of drops $\mathrm{cm}^{-2}$, being $26.5 \%$ higher than the volume of $130 \mathrm{~L}$ $\mathrm{ha}^{-1}$. The reduction in the spray volume from 160 to $40 \mathrm{~L} \mathrm{ha}^{-}$ ${ }^{1}$ reduced the number of drops $\mathrm{cm}^{-2}$ in $55.6 \%$ in the middle third of the plant, considering the application of R1 (Table 3 ) and R1 + 18 days (Table 4) where the volume reduction from 100 to $70 \mathrm{~L} \mathrm{ha}^{-1}$ and from 70 to $40 \mathrm{~L} \mathrm{ha}^{-1}$ represented variations on the order of $22 \%$, while the reduction on volume from 160 to $130 \mathrm{~L} \mathrm{ha}^{-1}$ and from 130 to $100 \mathrm{~L} \mathrm{ha}^{-1}$ represented a reduction of $14.5 \%$.

In the upper third of the plant, in the application of R1 (Table 3 ) and $R 1+18$ days (Table 4 ), the use of 130 or $160 \mathrm{~L} \mathrm{ha}^{-1}$, on average, showed no difference in the number of drops $\mathrm{cm}^{-2}$, although the reduction in spray volume from 160 to $40 \mathrm{~L} \mathrm{ha}^{-1}$ represented $47.6 \%$ decrease in the number of drops $\mathrm{cm}^{-2}$ with the greatest impacts observed when changed from 130 to $100 \mathrm{~L} \mathrm{ha}^{-1}$ and from 100 to $70 \mathrm{~L} \mathrm{ha}^{-1}$ which led to a reduction of 18.5 and $24.1 \%$ in drops number $\mathrm{cm}^{-2}$.

When using thick drops the risk of drift can be reduced, however, it can also reduce the efficiency of the products, as well as impair the distribution of the products throughout the plant (Gandolfo et al., 2014). Thus, it is of utmost importance that the droplet size is small enough to allow adequate coverage of the target, and large enough to have sufficient durability to traverse the distance between the point of its emission and the target, in a given environmental condition (Cunha et al., 2014), so the use of medium-grade drops appears as an alternative to minimize drift risks without compromising the leaf surface cover.
The percentage of the leaf surface cover was influenced by the spray volume and the use of the surfactant. Regardless of the spray volume the surfactant added to the mineral oil provided greater coverage of the leaf surface in the application in R1, and in R1 + 18 days, Table 5. The addition of the surfactant to the tank mix was responsible for increments of up to $16.3 \%$ in the coverage which was influenced by up to $208.5 \%$ in relation to the increase in spray volume. The greatest contribution of surfactant occurred in the low volumes where its presence provided differences close to $46 \%, 26 \%$ and $20 \%$ when used 40,70 and $100 \mathrm{~L} \mathrm{of} \mathrm{ha}^{-1}$, respectively.

In the lower, middle and upper third, in both applications the use of surfactant was less responsive to the increase in spray volume showing greater relevance as lower is the used volume, Table 5. In the lower third, in the application performed in R1, to the increase volume from 40 to $70 \mathrm{~L} \mathrm{ha}^{-1}$, it presented increase of $89.5 \%$ in the coverage when in absence of the surfactant, but when it was present in the tank mixture, the obtained variation reached levels of $40.6 \%$, as well as in the application performed in $\mathrm{R} 1+18$ days where the variation was on the order of $160.2 \%$ and $52.5 \%$, when in the absence and presence of surfactant, respectively, associated with a change in the spray volume from 40 to $70 \mathrm{~L} \mathrm{ha}^{-1}$. The same behavior was observed in all the studied volumes, which shows that the surfactant is a component that added to the tank mixture can minimize the negative effects of the reduction on application volumes, regarding the cover of leaf surface, considering that the use of surfactant plus oil optimized leaf coverage, especially in volumes below $100 \mathrm{~L} \mathrm{ha}^{-1}$ (Table 5).

Increase spray volume from 40 to $70 \mathrm{~L} \mathrm{ha}^{-1}$ as well as from 130 to $160 \mathrm{~L} \mathrm{ha}^{-1}$ with the use of mineral oil alone were not responsive in terms of increasing leaf surface coverage in the lower third of the plant in the application performed in R1, however, when these volumes were associated to surfactant they were significantly larger, especially the volume of 40 and $70 \mathrm{~L} \mathrm{ha}^{-1}$ where there were variations of up to 2.8 times in coverage. However, in the application performed at R1 + 18 days there were direct responses in terms of volume increase and surfactant use, except when the volume was changed from 40 to $70 \mathrm{~L} \mathrm{ha}^{-1}$ and only mineral oil was used (Table 5). 
TABLE 5. Coverage of leaf surface $(\%)$ in the R 1 stage and R1 stage +18 days, in the lower, middle and upper third and average on the leaf cover in the plant, as a function of the spray volume ( $\mathrm{L} \mathrm{ha}^{-1}$ ) and the combination of adjuvants in fungicide applications, Passo Fundo - RS, 2018.

\begin{tabular}{|c|c|c|c|c|}
\hline \multirow{3}{*}{$\begin{array}{l}\text { Volume } \\
\left(\mathrm{L} \mathrm{ha}^{-1}\right)\end{array}$} & \multicolumn{2}{|c|}{ Application in R1 } & \multicolumn{2}{|c|}{ Application in $\mathrm{R} 1+18$ days } \\
\hline & Mineral oil & $\begin{array}{c}\text { Mineral Oil and } \\
\text { Surfactant }\end{array}$ & Mineral oil & $\begin{array}{c}\text { Mineral Oil and } \\
\text { Surfactant }\end{array}$ \\
\hline & \multicolumn{4}{|c|}{$* * * * * * * * * *$ Lower third $* * * * * * * * *$} \\
\hline 40 & $1.9 \mathrm{cB}$ & $5.3 \mathrm{cA}$ & $1.3 \mathrm{~dB}$ & $4.6 \mathrm{eA}$ \\
\hline 70 & $3.6 \mathrm{cB}$ & $7.5 \mathrm{bcA}$ & $3.5 \mathrm{~dB}$ & $7.1 \mathrm{dA}$ \\
\hline 100 & $6.9 \mathrm{bB}$ & $10.3 \mathrm{bA}$ & $7.0 \mathrm{cB}$ & $10.9 \mathrm{cA}$ \\
\hline 130 & $10.2 \mathrm{aB}$ & $14.0 \mathrm{aA}$ & $9.8 \mathrm{bB}$ & $13.3 \mathrm{bA}$ \\
\hline 160 & $12.7 \mathrm{aB}$ & $16.5 \mathrm{aA}$ & $13.0 \mathrm{aB}$ & $16.4 \mathrm{aA}$ \\
\hline C.V. $(\%)$ & \multicolumn{2}{|c|}{14.6} & \multicolumn{2}{|c|}{10.3} \\
\hline Volume & \multicolumn{4}{|c|}{$* * * * * * * * * *$ Middle third $* * * * * * * * *$} \\
\hline 40 & $5.2 \mathrm{eB}$ & $9.7 \mathrm{dA}$ & $4.9 \mathrm{eB}$ & $8.9 \mathrm{dA}$ \\
\hline 70 & $8.9 \mathrm{~dB}$ & $16.3 \mathrm{cA}$ & $8.5 \mathrm{~dB}$ & $13.5 \mathrm{cA}$ \\
\hline 100 & $14.3 \mathrm{cB}$ & $21.9 \mathrm{bA}$ & $13.6 \mathrm{cB}$ & $21.3 \mathrm{bA}$ \\
\hline 130 & $22.0 \mathrm{bB}$ & $27.5 \mathrm{aA}$ & $21.5 \mathrm{bB}$ & $26.7 \mathrm{aA}$ \\
\hline 160 & $26.0 \mathrm{aB}$ & $29.4 \mathrm{aA}$ & $24.7 \mathrm{aB}$ & $28.5 \mathrm{aA}$ \\
\hline C.V. $(\%)$ & \multicolumn{2}{|c|}{10.2} & \multicolumn{2}{|c|}{15.8} \\
\hline Volume & \multicolumn{4}{|c|}{$* * * * * * * * * *$ Upper third $* * * * * * * * *$} \\
\hline 40 & $44.4 \mathrm{~dB}$ & $60.3 \mathrm{cA}$ & $45.3 \mathrm{~dB}$ & $62.0 \mathrm{cA}$ \\
\hline 70 & $64.6 \mathrm{cB}$ & $72.7 \mathrm{bA}$ & $65.3 \mathrm{cB}$ & $77.0 \mathrm{bA}$ \\
\hline 100 & $76.2 \mathrm{bB}$ & $87.3 \mathrm{aA}$ & 81.1 bB & 89.7 aA \\
\hline 130 & $83.7 \mathrm{aB}$ & $89.0 \quad \mathrm{aA}$ & $83.2 \mathrm{aB}$ & $90.2 \mathrm{aA}$ \\
\hline 160 & $87.4 \mathrm{aB}$ & $91.8 \mathrm{aA}$ & $89.7 \mathrm{aB}$ & $93.9 \mathrm{aA}$ \\
\hline C.V. $(\%)$ & \multicolumn{2}{|c|}{13.1} & \multicolumn{2}{|c|}{12.4} \\
\hline Volume & \multicolumn{4}{|c|}{$* * * * * * * * * *$ Overall average $* * * * * * * * *$} \\
\hline 40 & $17.2 \mathrm{eB}$ & $25.1 \mathrm{eA}$ & $17.2 \mathrm{eB}$ & $25.2 \mathrm{eA}$ \\
\hline 70 & $25.7 \mathrm{~dB}$ & $32.2 \mathrm{dA}$ & $25.8 \mathrm{~dB}$ & $32.5 \mathrm{dA}$ \\
\hline 100 & $32.7 \mathrm{cB}$ & $39.9 \mathrm{cA}$ & $33.9 \mathrm{cB}$ & $40.6 \mathrm{cA}$ \\
\hline 130 & $38.6 \mathrm{bB}$ & $43.5 \mathrm{bA}$ & $38.2 \mathrm{bB}$ & $43.4 \mathrm{bA}$ \\
\hline 160 & $42.0 \mathrm{aB}$ & $45.9 \mathrm{aA}$ & $42.3 \mathrm{aB}$ & $46.1 \mathrm{aA}$ \\
\hline C.V. $(\%)$ & \multicolumn{2}{|c|}{12.4} & \multicolumn{2}{|c|}{12.3} \\
\hline
\end{tabular}

Means followed by the same capital letter in the row and lowercase in the column do not differ by Tukey test, $5 \%$ probability.

In the middle third of the plant, the applications performed at R1 and R1 + 18 days presented a similar behavior where increases in the spray volume associated with mineral oil, increased the leaf surface coverage, reaching values close to $25 \%$ coverage when used $160 \mathrm{~L} \mathrm{ha}^{-}$ 1 , which reduced about $55 \%$ when it changed from 130 to $100 \mathrm{~L} \mathrm{ha}^{-1}$, as well as from 100 to $70 \mathrm{~L} \mathrm{ha}^{-1}$ being the coverage reduction more abruptly when it changed from 70 to $40 \mathrm{~L} \mathrm{ha}^{-1}$, varying about $74 \%$ (Table 5). However, when the surfactant was added to the tank mix, similar coverage was obtained with the use of 130 or $160 \mathrm{ha}^{-1}$, and in this third of the plant, the use of surfactant in the spray volume of 40 and $70 \mathrm{~L} \mathrm{ha}^{-1}$ provided an increase in coverage in the $85 \%$ range, reaching $52 \%$ when using $100 \mathrm{~L} \mathrm{ha}^{-1}$ (Table 5).
In the upper third, Table 5, in both evaluations there were significant responses regarding the use of surfactant. Regardless of spray volume, when it was present, the coverage percentage was similar, using 100,130 or $160 \mathrm{~L}$ $\mathrm{ha}^{-1}$, as well as, in the absence of the surfactant, the obtained coverage with spray volumes of 130 or $160 \mathrm{~L} \mathrm{ha}^{-1}$ show similar behavior. Although the effect on the imposed barrier by leaf mass in the upper plant extract is lower in relation to the medium and lower extracts, there were increases of up to $45 \%$ in the leaf surface cover in relation to volume increases and with the mineral oil use only, with the use of surfactant the increments were in the order of $20 \%$ where the volume of $40 \mathrm{~L} \mathrm{ha}^{-1}$ showed a greater response, with variations reaching $36 \%$, followed by the volumes of 70 and $100 \mathrm{~L} \mathrm{ha}^{-1}$, where there were responses on the order of $14 \%$, in relation to the use of surfactant in the tank mixture (Table 5). 
As for the spray volume, one of the ways to maximize the leaf surface cover, the growing increases studied demonstrate relevance, however, since certain limits tend to stagnate, so it is expected that the increased application volume provides an increase in the volume retained to some extent, from which the surface is no longer able to retain the liquid, and flowing occurs, which is not desirable (Cunha et al., 2008) so, volumes greater than 200 $\mathrm{L} \mathrm{ha}^{-1}$ did not provide increases in ASR control and did not reflect on productivity (Cunha \& Peres, 2010).

The AUDPC of the control, without fungicides application reached 1874 units along the plant canopy with 2003 units being computed in the lower third, 1667 units in the middle third and 1952 units of AUDPC in the upper third of the plant. The control AUDPC was significantly superior $(\mathrm{P}<0.05)$ than other treatments, indicating the ASR control, even with the lowest spray volumes.

Considering the average of the thirds of the plant, Table 6, there was a reduction in the AUDPC as the spray volume $\mathrm{ha}^{-1}$ increased, especially when the increase in volume was associated with the surfactant, however, in the largest evaluated volume, $160 \mathrm{~L} \mathrm{ha}^{-1}$, the surfactant use did not provide reduction in AUDPC. The ASR control was about $40 \%$ higher when the volume of $40 \mathrm{~L} \mathrm{ha}^{-1}$ was added the surfactant, and this difference was close to $23 \%$ when using $70 \mathrm{~L} \mathrm{ha}^{-1}$. The reduction in the spray volume from 160 to $40 \mathrm{~L} \mathrm{ha}^{-1}$ showed reduction of 2.3 times in the ASR control when in the absence of the surfactant, since with its use in the tank mixture there was decrease close to 1.7 times on the disease control.

The greatest control differentials in the plant canopy were observed when the volume was reduced from 130 to $100 \mathrm{~L} \mathrm{ha}^{-1}$ and from 100 to $70 \mathrm{~L} \mathrm{ha}^{-1}$ resulting in control drops of around $18 \%$, which came close to $27 \%$ when it was changed from 70 to $40 \mathrm{~L} \mathrm{ha}^{-1}$ without the use of surfactant, since in the presence of this, the greatest reduction on control occurred when the volume was reduced from 70 to $40 \mathrm{~L} \mathrm{ha}^{-1}$ reaching values close to $18 \%$, Table 6.

In the lower, middle and upper third of the plant the reduction in the spray volume $\mathrm{ha}^{-1}$ had direct relationship with the increase of the AUDPC, especially when in the absence of the surfactant, however the use of mineral oil in an isolated manner combined with $160 \mathrm{~L} \mathrm{ha}^{-1}$ did not impact on the amount of ASR, Table 6.
The highest AUDPC occurred in the lower third of the plant, Table 6 , which represented control in the order of $10.5 \%$, when $40 \mathrm{~L} \mathrm{ha}^{-1}$ and mineral oil were used in the spraying, being this control close to $23 \%$ when the surfactant was added which increased the control in the order of 2.3 times, and this behavior was also observed in the volumes of 70 and $100 \mathrm{~L} \mathrm{ha}^{-1}$ with variations close to 30 and $17 \%$, respectively.

In the lower third of the plant, Table 6 , the reduction in spray volume impacted in 6.8 times on ASR control when the volume was reduced from 160 to $40 \mathrm{~L} \mathrm{ha}^{-1}$ in the absence of the surfactant, reducing the control up to $68 \%$ when it changed from 70 to $40 \mathrm{~L}_{\text {of }} \mathrm{ha}^{-1}$ which the reduction of the other volumes from 160 to 130 , from 130 to 100 , from 100 to $70 \mathrm{~L} \mathrm{ha}^{-1}$ reached control reductions in order of $22 \%$. When the surfactant was added to the spraying, the volume reduction from 160 to $40 \mathrm{~L} \mathrm{ha}^{-1}$ represented drops of up to 3.1 times on disease control, however there was $45 \%$ reduction in the control from 70 to $40 \mathrm{~L} \mathrm{ha}^{-1}$.

In the middle third of the plant, Table 6 , the use of 130 and $160 \mathrm{~L} \mathrm{ha}^{-1}$ did not show significant differences on AUDPC, independent of the adjuvants combination, and in $160 \mathrm{~L} \mathrm{ha}^{-1}$ volume, surfactant use showed no relevance for the reduction of AUDPC. In this third of the plant the impacts on AUDPC reached 3.1 times and 2.8 times, as the spray volume was reduced from 160 to $40 \mathrm{~L} \mathrm{ha}^{-1}$ with the use of mineral oil or mineral oil plus surfactant, respectively. The control on soybean ASR was reduced by $70 \%$ compared to the higher volume in contrast to the lowest, in the absence of the surfactant remaining in the range of $50 \%$ when it was used. In the lower volumes, 40 and $70 \mathrm{~L} \mathrm{ha}^{-1}$, the surfactant optimized the ASR control up to 68 and $30 \%$, respectively.

In the upper third of the plant, Table 6 , the use of the surfactant showed no response in the ASR control when the volumes of 130 and $160 \mathrm{~L} \mathrm{ha}^{-1}$ were sprayed, being the control in the range of 80 and $87 \%$, respectively. However, for the other volumes, the control differences reached up to $17 \%$ being higher compared to the use of surfactant, especially in the lower volumes. When only mineral oil was used, the volumes of 40, 70 and $100 \mathrm{~L} \mathrm{ha}^{-1}$ did not show differences in the control, whereas, with the use of surfactant, only the volume of $160 \mathrm{~L}$ of ha- ${ }^{-1}$ showed greater disease control. 
TABLE 6. Area under the disease progression curve (AUDPC - units) and soybean Asian-rust control (\%) in the lower, middle, upper third and average of the plant, computed between V7 and R6, as a function of spray volume ( $\left.\mathrm{L} \mathrm{ha}^{-1}\right)$ and the combination of adjuvants in fungicide applications, Passo Fundo - RS, 2018.

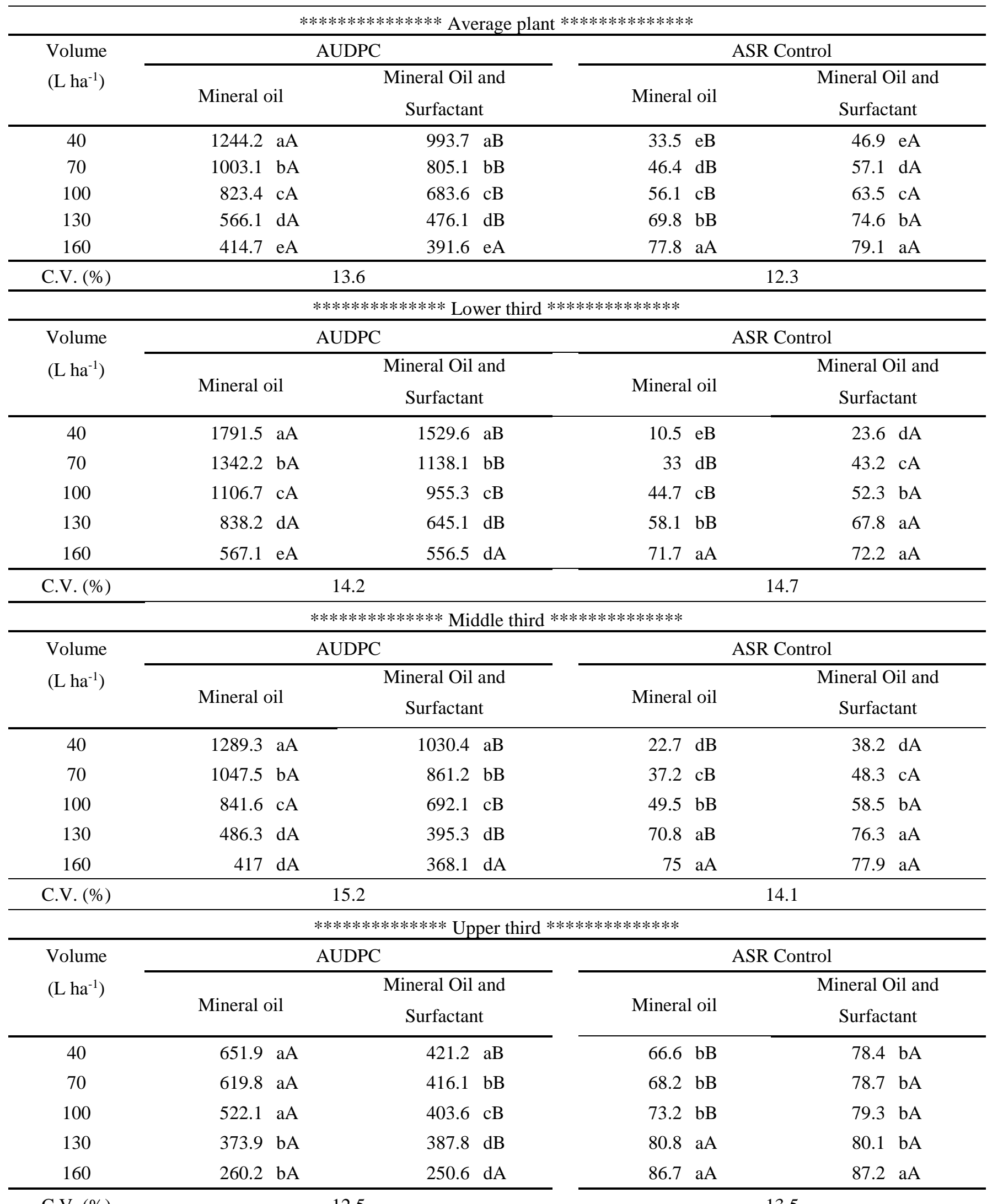

C.V. $(\%)$

12.5

13.5

Means followed by the same capital letter in the row and lowercase in the column do not differ by Tukey test, $5 \%$ probability. 
With the reduction in the spray volume, the coverage, the number of drops $\mathrm{cm}^{-2}$ and controlling ASR in all thirds of the plant were significantly affected, resulting in higher AUDPC, which shows that the magnitude of soybean protection to the disease varies according to the coverage and the penetration of drops provided by the application (Debortoli et al., 2012). In the spray volumes tested, the dependence on the organsilicone adjuvant was higher in relation to the reductions in the spray volume which compensated for the foliar surface cover, thus optimizing the disease control. However, in the volume of $160 \mathrm{~L} \mathrm{ha}^{-1}$, the use of organosilicone adjuvant was not determinant for the disease control, and did not differ in all thirds of the plant.

Spray techniques through hydraulic or centrifugal nozzles, with lower or higher application volume, offer low recovery of deposits and coverings in the middle and lower thirds of soybean plants causing low fungicide efficiency, and consequently low control levels (Boschini et al., 2008; Prado et al., 2010; Cunha et al., 2011).

The irregular distribution of the products in the lower canopy and inside the plant is one of the main causes of low efficiency on the ASR control (Boschini et al., 2008; Cunha et al., 2011; Cunha et al., 2016), thus, strategies are required to increase the deposition of spray droplets in this canopy stratum (Cunha et al., 2010; Cunha et al., 2011; Nascimento et al., 2013), in this way, techniques that allow a better distribution of the fungicide and the increase of the deposits in the middle and lower part can increase the fungicides efficiency in relation to ASR. Thus, ASR control can be increased with the use of larger spray volumes, changes in droplet size (use of lower spectrum drops when possible) and the use of adjuvants that increase the spread and cover on treated leaf surface (Carvalho et al, 2013, Cunha et al., 2014).

In developed research by Chechetto et al. (2014), it was observed that $70.7 \%$ of the interviewers use flat spray nozzles for the spraying of phytosanitary products, of which $31 \%$ use only one type of nozzle for all applications during the harvest with the majority of the interviewers use spray volume equal to or less than $100 \mathrm{~L} \mathrm{ha}^{-1}$ for insecticide, herbicide and fungicide applications, where there is preference for applications at lower rates and the use of medium to fine droplets in applications in the State of Mato Grosso, Brazil.

The distribution on plant cover showed a lack of uniformity, independent of the spray volume and adjuvant, which was approximately five times higher in the upper third of the plant, compared to the lower third, resulting from the largest number of drops in this third of the plant. Regarding to the number of drops, the eight times gradient was observed in the comparison of the upper third in relation to the lower third.

The penetration of droplets into the canopy of the culture is a fundamental factor for the chemical control of diseases, especially those that initiate the infectious process in the low third leaves, such as the ASR. However, it was observed that the maximum coverage obtained was of the order of $12 \%$ when the mineral oil was used alone, increasing to $16 \%$ when the surfactant was added, in the spray volume at $160 \mathrm{~L} \mathrm{ha}^{-1}$, where not exceeded 37 drops $\mathrm{cm}^{-2}$. The penetration and deposition of the active ingredient in leaves within the canopy is an essential condition for the effective control of the disease and, as the crop develops, reaching the lower layers of the canopy becomes increasingly difficult (Debortoli et al., 2012; Tormen et al., 2012).

In the tested volumes, the use of surfactant contributed to the maintenance of the remaining leaf area, except for the treatment with $160 \mathrm{~L}_{\text {of ha }}{ }^{-1}$, where its use did not increase the LAI in R6 in relation to the use of the mineral oil in an isolated manner, Table 7. In the volume of $40 \mathrm{~L} \mathrm{ha}^{-1}$ the use of the surfactant allowed the plant to maintain $184 \%$ more LAI at the end of the grain filling stage, whereas, with the volumes of 70 and $100 \mathrm{~L} \mathrm{ha}^{-1}$ differentials were observed near to $92 \%$ and $43 \%$, respectively, against the use of surfactant. The control, without application of fungicides, presented 0.18 units of LAI, being significantly inferior to the other treatments, indicating that the leaf area was maintained, even with the lowest spray volumes.

TABLE 7. Leaf area index (LAI) remaining in R6, as a function of spray volumes ( $\mathrm{L} \mathrm{ha}^{-1}$ ) and the combination of adjuvants in fungicide applications, Passo Fundo - RS, Brazil, 2018.

\begin{tabular}{crc}
\hline $\begin{array}{c}\text { Volume } \\
\left(\text { L ha }^{-1}\right)\end{array}$ & \multicolumn{3}{c}{ Adjuvant } \\
\cline { 2 - 3 } 40 & Mineral oil & Mineral Oil and Surfactant \\
70 & $0.39 \mathrm{~dB}$ & $1.11 \mathrm{cA}$ \\
100 & $1.06 \mathrm{cB}$ & $2.04 \mathrm{bA}$ \\
130 & $2.08 \mathrm{bB}$ & $2.98 \mathrm{aA}$ \\
160 & $2.43 \mathrm{aB}$ & $3.07 \mathrm{aA}$ \\
\hline
\end{tabular}

C.V. $(\%)$

12.5

Means followed by the same capital letter in the row and lowercase in the column do not differ by Tukey test, $5 \%$ probability. 
The increase in the spray volume ha ${ }^{-1}$ had a positive impact on the LAI, however, up to certain limits, since the volumes of 130 and $160 \mathrm{~L} \mathrm{ha}^{-1}$ do not show significant differences when used only with mineral oil as well as volumes of 100, 130 and $160 \mathrm{~L} \mathrm{ha}^{-1}$ did not provide higher LAI in R6, when the surfactant was added (Table 7).

The reduction in volume $\mathrm{ha}^{-1}$ resulted in LAI reductions close to $85 \%$, when it went from 160 to $40 \mathrm{~L} \mathrm{ha}^{-}$ ${ }^{1}$, being more abrupt in the reduction from 100 to 70 and later with the change from 70 to $40 \mathrm{~L} \mathrm{ha}^{-1}$, where there was reduction of 49 and $63 \%$ on LAI, respectively, when spraying was performed with mineral oil only. When the surfactant was present in the tank mixture, the contrast of the higher and lower volume used presented variations of approximately $62 \%$, with LAI reduced into the smallest volume. The highest variation occurred when changed from 70 to $40 \mathrm{~L} \mathrm{ha}^{-1}$ reaching about $45 \%$, followed by a reduction from 100 to $70 \mathrm{~L} \mathrm{ha}^{-1}$ where the remaining LAI reduced by approximately $32 \%$ (Table 7).

The grain yield obtained in the treatment without the fungicide application reached $1,971.1 \mathrm{~kg} \mathrm{ha}^{-1}$ with mass of one thousand grains of $101.45 \mathrm{~g}$, showing to be significantly inferior $(\mathrm{P}<0.05)$ to the other treatments, indicating the partial preservation of the grain yield potential, compared to the ASR control, even with the lower spray volumes. The participation of thirds in the yield and grain yield in each of the evaluated thirds, lower, middle and higher, showed significance $(\mathrm{P}<0.05)$ for the interaction among spray volumes and adjuvants.

The yield of grains and the mass of 1000 grains, Table 8 , were reduced when reductions occurred in the spray volume of the sprays, the reductions being less accentuated when was added surfactant in the tank mixture. The grain yield was reduced by $25 \%$ when the spray volume was changed from 160 to $40 \mathrm{~L} \mathrm{ha}^{-1}$ using mineral oil in an isolated manner from $3,971.8 \mathrm{~kg} \mathrm{ha}^{-1}$ to $3,005.5 \mathrm{~kg} \mathrm{ha}^{-1}$ and reductions observed in the order of 8 and $12 \%$ when the volume was reduced from 100 to 70 and later from 70 to 40 $\mathrm{L} \mathrm{ha}^{-1}$, respectively, representing about 420 and $362 \mathrm{~kg}$ ha ${ }^{1}$, for the cited volumes.

Yield declines were minimized as the surfactant was used, and in the volume of $40 \mathrm{~L} \mathrm{ha}^{-1}$, yield differentials were observed in the order of $14 \%$, compared to surfactant which reached $11 \%$ and $9 \%$ with the volumes of 70 and $100 \mathrm{~L} \mathrm{ha}^{-}$ ${ }^{1}$, respectively. In the volumes of 130 and $160 \mathrm{~L} \mathrm{ha}^{-1}$, the use of the surfactant did not optimize the soybean yield compared to the oil use, as well as its use there was no significant difference between the volumes of 100, 130 and $160 \mathrm{~L} \mathrm{ha}^{-1}$, whereas, with the isolated use of the mineral oil, the volumes of 130 and $160 \mathrm{~L} \mathrm{ha}^{-1}$ showed no differences in yield, Table 8 .

TABLE 8. Grain yield $\left(\mathrm{kg} \mathrm{ha}^{-1}\right)$ and mass of one thousand grains $(\mathrm{g})$ according to the spray volume $\left(\mathrm{L} \mathrm{ha}^{-1}\right)$ and the combination of adjuvants in the fungicide applications, Passo Fundo - RS, 2018.

\begin{tabular}{|c|c|c|c|c|}
\hline \multirow{2}{*}{$\begin{array}{l}\text { Volume } \\
\left(\mathrm{L} \mathrm{ha}^{-1}\right)\end{array}$} & \multicolumn{2}{|c|}{ Yield $\left(\mathrm{kg} \mathrm{ha}^{-1}\right)$} & \multicolumn{2}{|c|}{ Mass of one thousand grains (g) } \\
\hline & Mineral oil & Mineral Oil and Surfactant & Mineral oil & Mineral Oil and Surfactant \\
\hline 40 & $3,005.5 \mathrm{~dB}$ & $3,409.3 \mathrm{cA}$ & $140.6 \mathrm{~dB}$ & $145.4 \mathrm{cA}$ \\
\hline 70 & $3,424.8 \mathrm{cB}$ & $3,816.6$ bA & $144.6 \mathrm{cB}$ & $146.9 \mathrm{bcA}$ \\
\hline 100 & $3,733.9$ bB & $4,069.1 \mathrm{aA}$ & $146.4 \mathrm{bcB}$ & $150.9 \mathrm{aA}$ \\
\hline 130 & $3,955.6$ aA & $4,078.1$ aA & $149.5 \mathrm{aA}$ & $150.3 \mathrm{aA}$ \\
\hline 160 & $3,971.8 \quad \mathrm{aA}$ & $4,025.2 \mathrm{aA}$ & $149.2 \mathrm{aA}$ & $149.6 \mathrm{aA}$ \\
\hline C.V. $(\%)$ & & 11.9 & & 10.8 \\
\hline
\end{tabular}

Means followed by the same capital letter in the row and lowercase in the column do not differ by Tukey test, $5 \%$ probability.

The thousand grains mass, Table 8, presented similar behavior to the grain yield, where with the isolated use of mineral oil, the volumes of 130 and $160 \mathrm{~L} \mathrm{ha}^{-1}$ did not show significant differences, as well as the volumes of 100, 130 and $160 \mathrm{~L} \mathrm{ha}^{-1}$ showed similar behavior when sprayed with the presence of surfactant. In the lower evaluated volumes, the use of surfactant contributed to increases in one thousand grains mass up to $3 \%$, especially in the volume of $40 \mathrm{~L} \mathrm{ha}^{-1}$.

Regarding to grain yield distribution it was observed that the lower third of the plant contributed between $5.7 \%$ and $18.9 \%$ of the yield, while in the middle third the contribution was between $26.3 \%$ and $45.1 \%$ and the upper third was responsible for $36.2 \%$ to $67.9 \%$ of the yield, as shown in Table 9. As there were reductions in the spray volume $\mathrm{ha}^{-1}$, independent of the adjuvants, the lower and middle portions of the plant had a lower contribution on the final yield, so the upper third of the plant acquired greater importance on this variable, as the spray volume increased, there was greater equivalence on distribution throughout the plant.
Productivity damages are a reflection of a set of effects that ASR causes on soybean, such as early defoliation, leaf area reduction and reduction of dry mass accumulation (Kumidini et al., 2008), since the greater the severity of the disease, the larger the number of uredinia per unit area, thus the greater interference in the leaf metabolism and the greater the loss of water, with reflex on the longevity of the leaflets (Garcés-Fiallos \& Forcelini, 2013; Twizeyimana et al., 2011), Thus, the use of fungicides, aiming to control the disease, reduces the damage resulting in larger leaf area during grain filling which directly influences yield components (Godoy et al., 2009; Godoy et al. 2016).

Fungicide applications with different spray volume may result in different levels of ASR control, especially when grown in cultivars with different architectures (Madalosso et al., 2010. Still, with the reduction of water for the same active ingredient amount, less dilution occurs, demanding greater precision in the application. Therefore, the reduction of the volume ha ${ }^{-1}$ brings risks directly linked to the control efficiency of the fungicide and its residual (Madalosso et al., 2010). 
TABLE 9. Participation in yield $(\%)$ and grain yield $\left(\mathrm{kg} \mathrm{ha}^{-1}\right)$ of the lower, middle and upper third of the plant, as a function of the spray volume $\left(\mathrm{L} \mathrm{ha}^{-1}\right)$ and the combination of adjuvants in fungicide applications, Passo Fundo - RS, 2018.

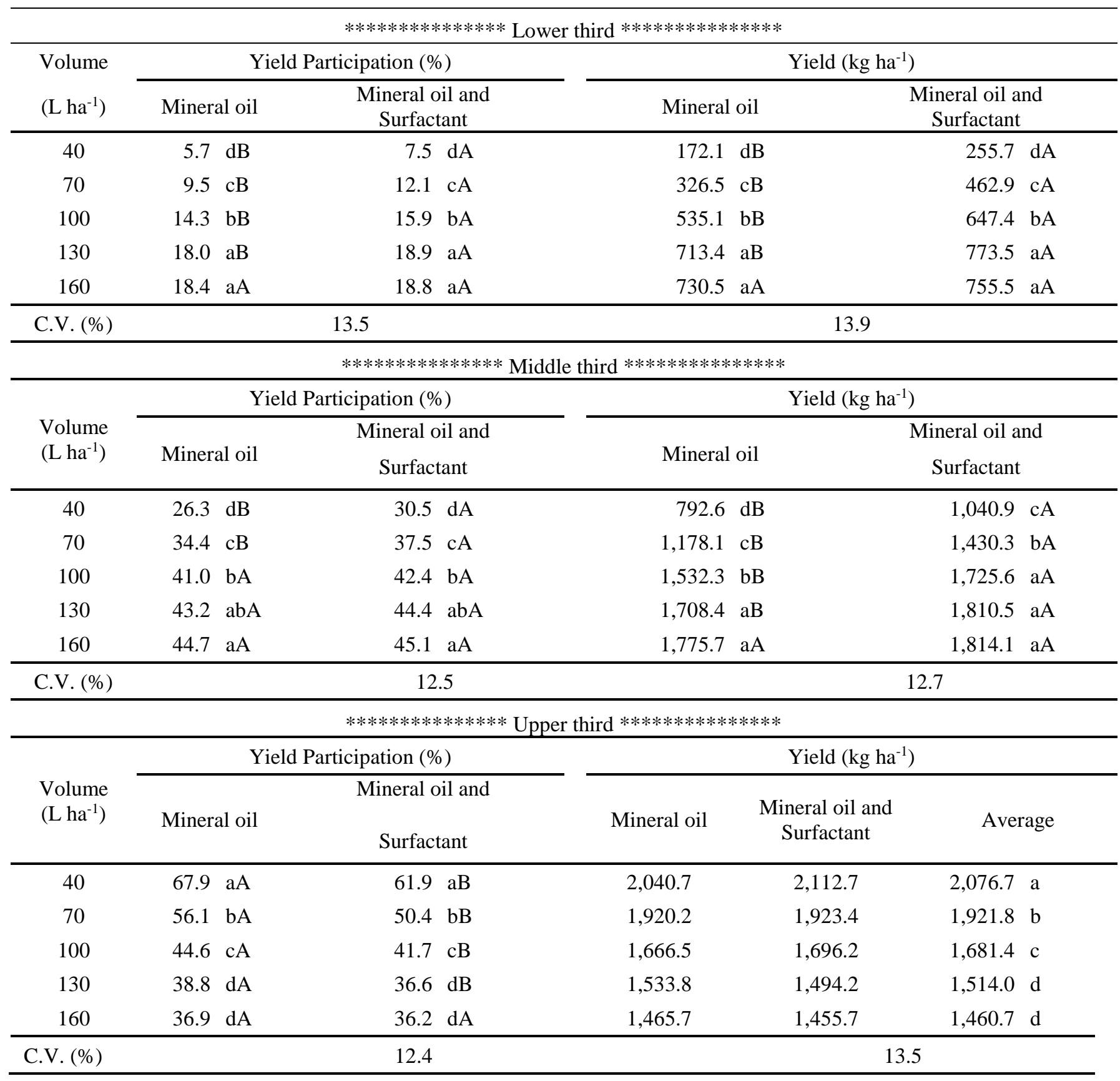

Means followed by the same capital letter in the row and lowercase in the column do not differ by Tukey test, $5 \%$ probability.

In the lower third of the plant, Table 9, the increases in the spray volume with isolated use of mineral oil, increased by 3.2 times the participation of that third on the final yield, whereas when surfactant was added to the tank mixture, the increases in yield are in the range of 2.5-times, since the impacts on volume reduction were minimized by the surfactant, especially in the 40 and $70 \mathrm{~L} \mathrm{ha}^{1}$ which allowed increases of approximately 31 and $27 \%$, respectively, in the yield. However, in the volumes of 130 and $160 \mathrm{~L} \mathrm{ha}^{-1}$, no differences were observed in terms of participation in the yield when the mineral oil was used alone or in association with the surfactant.

The grain yield observed in the lower third, Table 9, ranged about 4.3 times and 2.9 times, when the mineral oil was used alone or when it was added to the surfactant, respectively. The increase in spray volume from 40 to 70 , from 70 to 100 and from 100 to $130 \mathrm{~L} \mathrm{ha}^{-1}$, represented about $89 \%, 64 \%$ and $33 \%$ more yield in the lower third of the plant when the mineral oil was used alone, however, as the surfactant was added to the tank mixture there were less abrupt variations on yield, being $81 \%, 39 \%$ and $19 \%$ for that volume increases. Also, in $40 \mathrm{~L} \mathrm{ha}^{-1}$ volume, the use of the surfactant in the tank mixture, in relation to the isolated use of the mineral oil, represented $48 \%$ more yield in the lower third, whereas for the volume of $70 \mathrm{~L} \mathrm{ha}^{-1}$ the differential reached around $42 \%$, being $21 \%$ for the volume of $100 \mathrm{~L}$ $\mathrm{ha}^{-1}$.

In the middle third of the plant, Table 9, the use of the surfactant together with mineral oil in the spray volumes from $100 \mathrm{~L} \mathrm{ha}^{-1}$ did not contribute to increase the participation of that third in the yield of grains, which was 
between 41 and $45 \%$. However, in the smaller volumes 40 and $70 \mathrm{~L} \mathrm{ha}^{-1}$, there were increases close to 16 and $9 \%$, respectively. The increase in the spray volume from 40 to $70 \mathrm{~L} \mathrm{ha}^{-1}$ and later from 70 to $100 \mathrm{~L} \mathrm{ha}^{-1}$ led to increases of $30 \%$ and $19 \%$, respectively on the participation of the middle third in the yield in the absence of the surfactant being the differentials close to $22 \%$ and $13 \%$ when the surfactant was used, in the referred volumes.

The middle third of the plant had variations in yield between 792.6 and $1814.1 \mathrm{~kg} \mathrm{ha}^{-1}$ due to the combination of adjuvants and variations in the spray volume, Table 9 . In the absence of the surfactant, the increase in the spray volume represented the increase in yield in the order of 2.3 times, where the greatest contributions occurred with the increase in the volume of $40 \mathrm{~L} \mathrm{ha}^{-1}$ to $70 \mathrm{~L} \mathrm{ha}^{-1}$ with an increase close to $49 \%$ and in the change from 70 to $100 \mathrm{~L} \mathrm{ha}^{-1}$, reaching levels close to $30 \%$. As the surfactant was used, the differentials in volume increases were attenuated, since, in contrast, the differences observed in relation to the lowest and the highest tested volume reached 1.7 times, with levels of $37 \%$ and $20 \%$, ranging from 40 to $70 \mathrm{~L} \mathrm{ha}^{-1}$ and from 70 to $100 \mathrm{~L} \mathrm{ha}^{-1}$, respectively. In the higher spray volume evaluated there was no increase in yield when using surfactant.

The upper third of the plant, Table 9, showed interaction between the spray volume and the combination of adjuvants as regard to the participation of the upper third in the yield, however, the yield of grains was significant only for the spray volumes.

As the spray volume $\mathrm{ha}^{-1}$ increased there was a higher participation of the lower and middle thirds in the yield of grains, thus, with the lower volumes sprayed there was the smallest participation in the yield. Thus, in the 40 , 70 and $100 \mathrm{~L} \mathrm{ha}^{-1}$ volumes there was higher concentration of yield in the upper third of the plant reaching about $68 \%$ when pulverized $40 \mathrm{~L} \mathrm{ha}^{-1}$ combined with mineral oil. The use of surfactant reduced the influence of the upper third in the yield compared to the better distribution in the other parts of the plant, and the same behavior was observed for spray volume, that, as they increased, minimized the importance and supremacy of the third on yield, which was better distributed throughout the plant.

As the leaf surface coverage and the number of drops $\mathrm{cm}^{-2}$ were reduced, there was an increase in ASR severity, resulting in higher AUDPC, and lower disease control, directly affecting the remaining LAI in R6, as well as thousand grains mass and grain yield in all strata of the plant, interfering with the participation of thirds in yield.

In the spray volumes evaluated, the surfactant utilization shown to be feasible, increasing the leaf surface coverage, reducing AUDPC, maximizing ASR control, collaborating for the maintenance of LAI and positively impacting grain yield, especially in the volumes of 40,70 , 100 and $130 \mathrm{~L} \mathrm{ha}^{-1}$, as solutions containing organosilicone surfactant promote spreading increments, maximizing adherence and penetration of phytosanitary products (Iost \& Raetano, 2010; Zyl et al., 2010; Cunha et al., 2011, Garcia et al., 2016). Thus, the surfactant addition to the tank mixture optimizes the coverage with reflection on the ASR severity, however, does not impact on the amount of the agrochemical deposit (Prado et al., 2015).
Due to the alteration of the sensitivity of $P$. pachyrhizi to specific fungicides site (demethylation inhibitor, quinone outside inhibitors and succinate dehydrogenase inhibitors) and since fungicides with new mechanisms of action are not available, multisite fungicides (mancozeb, chlorothalonil, copper sulphate, among others) were used in the management of ASR, in formulated mixtures or tank mixtures with those of specific site, in order to increase the control efficiency, as well as to mitigate the resistance risks of the fungus (Juliatti et al., 2017; Godoy et al., 2016, Silva et al., 2015, Gullino et al., 2010). The fungicides with multisite action interfere in several cellular functions, being classified as immobile and acting as a protective surface barrier to infection, so they are non-penetrating or immobile, and when applied to the aerial parts they are not absorbed and therefore are not translocated, remaining on the surface of the plant where they were deposited (Reis et al., 2010).

Due to the characteristic of the multisite fungicides the leaf surface cover has great importance on the efficiency control of the ASR. Thus, increases in spray volume, as well as the use of surfactant can optimize the management of the disease, since the increase in spray volume, besides increasing leaf cover, provides greater deposition on the middle and lower third of the plant, as well as the use of surfactant, provides increases in leaf cover, especially with reduced spray volumes.

\section{CONCLUSIONS}

The greater dependence of the surfactant occurs in the low spray volumes where it provides increases in the leaf surface cover, optimizing the control of the Asian-rust, maximizing the index of leaf area, and the grains yield. The applications with greater spray volume do not require the use of surfactant without compromising the coverage, optimizing the density of droplets throughout the plant, reflecting on the control of the Asian-rust in the maintenance of the leaf area index, and in the grain yield.

\section{REFERENCES}

Almeida R, Forcelini CA, Garcés-Fiallos, FR (2017)

Chemical control of foliar diseases in soybean depends on cultivar and sowing date. Bioscience Journal 33(5):11881196.

Boschini L, Contiero RL, Macedo Junior EK, Guimarães VF (2008) Avaliação da deposição da calda de pulverização em função da vazão e do tipo de bico hidráulico na cultura da soja. Acta Scientiarum 30(2):171175.

Carvalho FK, Antuniassi, UR, Mota AAB, Chechetto RG, Gandolfo UD (2013) Adjuvantes na deposição de aplicações aéreas e terrestres. Energia na agricultura 28(4):215-221.

Chechetto RG, Mota AAB, Antuniassi UR, Carvalho FK, Vilela CM, Silva ACA (2014) Caracterização da taxa de aplicação e pontas de pulverização utilizadas no Estado de Mato Grosso. Magistra 26(1):89-97. 
Chechetto RG, Antuniassi UR, Mota AAB, Carvalho FK, Silva ACA; Vilela CM (2013) Influência de pontas de pulverização e adjuvantes no potencial de redução de deriva em túnel de vento. Semina: Ciências Agrárias 34(1):37-46.

Cunha JPA, Marques RS, Alves GS (2016) Deposição da calda na cultura da soja em função de diferentes pressões de trabalho e pontas de pulverização. Ceres 63(6):761-768.

Cunha JPAR, Juliatti FC, Reis EF (2014) Tecnologia de aplicação de fungicidas no controle da ferrugem asiática da soja: resultados de oito anos de estudos em Minas Gerais e Goiás. Bioscience Journal 30(4):950-957.

Cunha JPAR, Farnese AC, Olivet JJ, Villalba, J (2011) Deposição de calda pulverizada na cultura da soja promovida pela aplicação aérea e terrestre. Engenharia Agrícola 31(2):343-351.

Cunha JPAR, Peres TCM (2010) Influência de pontas de pulverização e adjuvante no controle químico da ferrugem asiática da soja. Acta Scientiarum 32(4):597-602.

Cunha JPAR, Coelho L, Araújo RGC (2010) Spray nozzle and adjuvant effects on fungicidal control of soybean Asian rust. Interciência 35(10):765-768.

Cunha JPAR, Silva RAM (2010) Uniformidade de distribuição volumétrica de pontas de pulverização em função da pressão de trabalho e altura da barra. Bioscience Journal 26(1):52-58.

Cunha JPAR, Moura EAC, Silva Junior JL, Zago FA, Juliatti FC (2008) Efeito de pontas de pulverização no controle químico da ferrugem da soja. Engenharia Agrícola 28(2):283-291.

Cunha JPAR, Reis EF, Santos RO (2006) Controle químico da ferrugem asiática da soja em função de ponta de pulverização e volume de calda. Ciência Rural 36(5):1360-1366.

Debortoli MP, Tormen NR, Balardin RS, Fávera DD, Stefanello MT, Pinto FF, Uebel JD (2012) Efeito dos espectros de gota associados a diferentes arquiteturas de cultivares de soja no controle da ferrugem. Pesquisa Agropecuária Brasileira 47(7):920-927.

Fehr WR, Caviness CE, Burmood DT, Pennington JS (1971) Stage of development descriptions for soybeans, Glycine max (L.) Merrill. Crop Science 11:929-931.

Gandolfo MA, Carvalho FK, Chechetto RG, Gandolfo UD, Moraes ED (2014) Effect of working pressure at different spray nozzles on drift quantification in wind tunnel. Engenharia Agrícola 34(1):66-73.

Garcés-Fiallos FR, Forcelini CA (2013) Controle comparativo da ferrugem asiática da soja com fungicida triazol ou mistura de triazol + estrobilurina. Bioscience Journal 29(4):805-815.

Garcia CG, Machado Júnior CR, Bochnia GP, Neto PHW, Raetano CG (2016) Adjuvants in fungicide spraying in wheat and soybean crops. Engenharia Agrícola 36(6):1110-1117.
Godoy CV, Seixas CD, Soares RM, Guimarães FCM, Meyer MC, Costamilan LM (2016) Asian soybean rust in Brazil: past, present, and future. Pesquisa Agropecuária Brasileira 51(5):407-421.

Godoy CG, Flausino AM, Santos LCM, Del Ponte EM (2009) Eficiência do controle da ferrugem asiática da soja em função do momento de aplicação sob condições de epidemia em Londrina, PR. Tropical Plant Pathology 34(1):56-61.

Godoy CV, Koga LJ, Canteri MG (2006) Diagrammatic Scale for Assessment of Soybean Rust Severity.

Fitopatologia Brasileira 31(1):63-68.

Gullino ML, Tinivella F, Garibaldi A, Kemmitt GM, Bacci L, Sheppard B (2010) Mancozeb, past, present and future. Plant Disease 94(9):1076-1087.

Holtz V, Couto RF, Oliveira DG, Reis EF (2014) Deposição de calda de pulverização e produtividade da soja cultivada em diferentes arranjos espaciais. Ciência Rural 44(8):1371-1376.

Iost CAR, Raetano CG (2010) Tensão superficial dinâmica e ângulo de contato de soluções aquosas com surfatantes em superfícies artificiais e naturais. Engenharia Agrícola 30(4):670-680.

Juliatti FC, Polloni LC, Morais TP, Zacarias NRS, Silva EA, Juliatti BCM (2017) Sensitivity of Phakopsora pachyrhizi populations to dithiocarbamate, chloronitrile, triazole, strobilurin, and carboxamide fungicides.

Bioscience Journal 33(4):933-943.

Kimati H, Bergamin Filho A, Amorim L (2011) Princípios gerais de controle. In: Amorim L, Rezende JAM, Bergamin Filho A. Manual de fitopatologia: princípios e conceitos. Piracicaba, Agronômica Ceres, 4 ed. p 307-323.

Kumidini S, Godoy CV, Board JE, Omielan J, Tollenaat M (2008) Mechanisms involved in soybean rust-induced yield reduction. Crop Science 48(6):2334-2341.

Langenbach C, Campe R, Beyer SF, Mueller AN, Conrath U (2016) Fighting Asian Soybean Rust. Plant Science 7:114.

Madalosso MG, Domingues LS, Debortoli MP, Lenz G, Balardin RS (2010) Cultivares, espaçamento entrelinhas e programas de aplicação de fungicidas no controle de Phakopsora pachyrhizi Sidow em soja. Ciência Rural 40(11):2256-2261.

Melo CLP, Roese AD, Goulart ACP (2015) Tolerância de genótipos de soja à ferrugem-asiática. Ciência Rural 45(8):1353-1360.

Nascimento JM, Gavassoni WL, Souza CMA, Bacchi LMA, Serra AP, Zaccaron ML (2013) Pontas de pulverização e horários de aplicação no controle químico de ferrugem asiática da soja. Semina: Ciências Agrárias 34(5):2037-2048. 
Prado EP, Raetano CG, Dal Pogetto MHF, Costa SAI, Christovam RS (2015) Taxa de aplicação e uso de surfactante siliconado na deposição da pulverização e controle da ferrugem da soja. Engenharia Agrícola 35(3):514-527.

Prado EP, Raetano CG, Aguiar Júnior HO, Dal Pogetto MHFA, Christovam RS, Gimenes MJ, Araújo D (2010) Velocidade do ar em barra de pulverização na deposição da calda fungicida, severidade da ferrugem asiática e produtividade da soja. Summa Phytopathologica 36(1):45-50.

Reis EM, Deuner E, Zanatta M (2015) In vivo sensitivity reduction of Phakopsora pachyrhizi to tebuconazol. Summa Phytopathologica 41(1):21-24.

Reis EM, Reis AC, Carmona M, Danelli ALD (2012) Ferrugem Asiática. In: Reis EM, Casa RT (Orgs). Doenças da soja. Berthier, p 69-101.

Reis EM, Reis AC, Carmona MA (2010) Manual de Fungicidas: guia para o controle químico de doenças das plantas. Passo Fundo, Universidade de Passo Fundo, 6 ed. $226 \mathrm{p}$.

Silva LHCP, Campos HD, Silva JRC, Reis EM (2015) Controle da ferrugem asiática da soja com mancozebe um fungicida multissítio. Summa Phytopathologica 41(1):64-67.
Schmitz HK, Medeiros CA, Craigc IR, Stammlerd G (2013) Sensitivity of Phakopsora pachyrhizi towards quinone-outside-inhibitors and demethylation-inhibitors, and corresponding resistance mechanisms. Pest Management Science 70(3):378-388.

Spanoghe P, Schampheleire M, Meeren PV, Steurbaut W (2007) Influence of agricultural adjuvants on droplet spectra. Pest Management Science 63(4):4-16.

Tormen NR, Silva FDL, Debortoli MP, Uebel JD, Fávera DD, Balardin RS (2012) Deposição de gotas no dossel e controle químico de Phakopsora pachyrhizi na soja. Revista Brasileira de Engenharia Agrícola e Ambiental 16(7):802-808.

Twizeyimana M, Ojiambo PS, Hartman GL, Bandyopadhyay R (2011) Dynamics of soybean rust epidemics in sequential plantings of soybean cultivars in Nigeria. Plant Disease 95(7):43-50.

Villalba JF, Dagoberto M, Costa NV, Domingos VD (2009) Deposição da calda de pulverização em cultivares de soja no estádio R1. Ciência Rural 39(6):1738-1744.

Zyl SAV, Brink J, Calitz FJ, Coertze S, Fourie PH (2010) The use of adjuvants to improve spray deposition and Botrytis cinerea control on Chardonnay grapevine leaves. Crop Protection 29(6):58-67. 